\title{
EVALUASI KANDUNGAN LIGNIN DAN TANNIN PADA KULIT PISANG GOROHO (Musa Acuminafe, $s p$ ) FERMENTASI SEBAGAI PAKAN TERNAK AYAM RAS PETELUR
}

\author{
Evaluation of Lignins and Tannins in the Goroho Bananas Peel (Musa Acuminafe, Sp) \\ Fermented as Feed for Laying Chickens
}

Fatma Husain *1), Syamsul Bahri²), dan Syukri I Gubali2)

${ }^{1}$ Alumni Fakultas Pertanian Universitas Negeri Gorontalo

2Jurusan Peternakan Fakultas Pertanian Universaitas Negeri Gorontalo

Corresponding Author: email: fatmahusain339@gmail.com.

\begin{abstract}
The objective of this study was to determine the content of lignin and tannin in the peel of Goroho banana fermented as laying hens' feed. It was arranged based on a completely randomized design with 4 treatments and 3 replications. The treatments were $\mathrm{P} 0=$ Goroho banana's peel without fermentation, $\mathrm{P} 1=$ Goroho banana's peel fermented with $0,3 \%$ Rhyzopus Olygosporus, $\mathrm{P} 2=$ Goroho banana's peel fermented with $0,3 \%$ Trichoderma viride, $\mathrm{P} 3=$ goroho banana's peel fermented with $0,15 \%$ Rhyzopus olygosporus $+0,15 \%$ Trichoderma viride. The Data were analyzed by the least significant differences at the $1 \%$ level. Findings The results of the study showed that the nutrition of Goroho banana's peels fermented as laying hens' feed has significant differences with lignin and tannin $(\mathrm{P}<0.01)$. The lowest lignin content was in treatment P3 $(16,23)$, while the lowest tannin content was in treatment P1 $(0,20)$. It can be concluded that the Goroho banana's peel that can be utilized as laying hens' feed was the peel that had been fermented with 1,5\% Rhyzopus olygosporus + 1,5\% Trichoderma viride containing 16,23\% lignin. However, the peel fermented with Rhizopus olygosporus contained tannin for $0,20 \%$.
\end{abstract}

Keywords: fermentation, nutrition, Goroho banana's peel

\begin{abstract}
ABSTRAK
Penelitian ini bertujuan untuk mengetahui kandungan lignin dan tanin kulit pisang goroho hasil fermentasi sebagai pakan ayam petelur., Penelitian ini menggunakan Rancangan Acak Lengkap (RAL), dengan 4 perlakuan dan 3 ulangan. Perlakuan yang dilakukan adalah P0 = kulit pisang goroho tanpa fermentasi, P1 = kulit pisang goroho yang difermentasi dengan Rhyzopus olygosporus $0,3 \%, \mathrm{P} 2$ = kulit pisang goroho yang difermentasi dengan Trichoderma viride $0,3 \%, \mathrm{P} 3=$ kulit pisang goroho yang difermentasi dengan Trichoderma olygosporus $0,15 \%+0,15 \%$. viride. Data dianalisis dengan perbedaan paling signifikan pada taraf $1 \%$. Hasil penelitian menunjukkan bahwa nutrisi kulit pisang goroho yang difermentasi sebagai pakan ayam petelur memiliki perbedaan yang nyata dengan lignin dan tanin $(\mathrm{P}<0,01)$. Kadar lignin terendah pada perlakuan $\mathrm{P} 3(16,23)$, sedangkan kadar tanin terendah pada perlakuan P1 $(0,20)$. Dapat disimpulkan bahwa kulit pisang goroho yang dapat dijadikan pakan untuk ayam petelur adalah kulit yang telah difermentasi dengan 1,5\% Rhyzopus olygosporus $+1,5 \%$ Trichoderma viride yang mengandung 16,23\% lignin. Sedangkan kulit yang difermentasi dengan Rhyzopus olygosporus mengandung 0,20\% tanin.
\end{abstract}

Kata Kunci : Fermentasi, Nutrisi, Pisang Goroho

Cara Mengutip (APA Citation Style)

Husain F, Bahri S, dan. Gubali S.I., 2020 Evaluasi Kandungan Lignin Dan Tannin Pada Kulit Pisang Goroho (Musa Acuminafe, Sp) Fermentasi Sebagai Pakan Ternak Ayam Ras Petelur. Jambura Journal of Animal Science, 3(1), 26-30

(C) 2020 - Husain F, Bahri S, dan Gubali S.I. Under the license CC BY-SA 4.0 


\section{PENDAHULUAN}

Produksi telur di Indonesia tidak selalu mengalami kenaikan maupun penurunan produksi telur yang dicapai merupakan akibat 2 faktor yaitu laju produksi telur dan lama produksi telur. Kemampuan produksi telur dipengaruhi oleh faktor genetik dan faktor lingkungan. Selain itu konsumsi telur dihasilkan oleh ayam ras petelur merupakan salah satu jenis unggas yang diternakkan di Indonesia. Produksi telur dan konsumsi telur saling keterkaitan ketika produksi telur mengalami kenaikan konsumsi telur pun meningkat. Namun peningkatan produktivitas dan konsumsi ayam petelur perlu dilakukan usaha untuk meningkatkan produktivitas ayam petelur, salah satunya melalui perbaikan sistem pemeliharaan dan pemberian pakan.

Sehingga dibutuhkan pakan yang mampu meningkatkan kebutuhan produksi telur pada ayam ras petelur sala satu faktor peningkatan produksi telur adalah pakan, hanya kendalanya pakan yang tersedia yang paling banyak pakan pabrikan yang harganya mahal sehingga mempengaruhi produktifitas ternak begitu tingginya harga pakan pabrikan terutama kosentrat maka perlu dicarikan alternatif bahan pakan yang bisa menjadi sumber pakan bagi ternak ayam ras petelur sala satu sumber bahan pakan yang potensial yang untuk dijadikan sala satu bahan pakan adalah limbah pertanian seperti kulit pisang goroho.

Pemanfaatn limbah pertanian seperti kulit pisang dijadikan sebagai pakan ternak khususnya unggas memiliki kendala dalam hal kualitas nutrien dan kecernaan. Pakan unggas mengharuskan suatu bahan pakan memiliki kandungan nutrisi yang baik dan rendah serat kasar, sedangkan kulit pisang masih mengandung serat kasar yang tinggi serta kandungan protein yang rendah. Oleh karena itu untuk memanfaatan kulit pisang sebagai pakan ayam ras petelur. memerlukan fermentasi terlebih dahulu sebelum digunakan sebagai pakan ayam ras petelur.

Kegiatan Fermentasi merupakan salah satu upaya untuk meningkatkan nilai gizi bahan pakan berkualitas rendah dengan bantuan mikroorganisme seperti Rhizopus olygosporus dan Tricohoderma viride. Untuk itulah dilakukan penilitian tentang evaluasi untuk mengetahui kadar lignin dan tannin pada kulit pisang goroho. Tujuan penelitian ini untuk mengetahui kandungan lignin dan tannin pada kulit pisang goroho terfermentasi sehingga dapat dijadikan sebagai pakan ternak

\section{METODE PENELITIAN}

Penelitian ini telah dilaksanakan pada bulan April sampai bulan Mei 2019. Pembuatan fermentasi dilakukan di Laboratorium Pertanian Terpadu Universitas Negeri Gorontalo dan untuk penelitian penentuan analisis kandungan nutrisi dilakukan di Laboratorium Kimia Dan Nutrisi Makanan Ternak Jurusan Nutrisi Fakultas Peternakan Universitas Hassanudin, makasar

\section{Rancangan Penelitian}

Penelitian menggunakan

Rancangan Acak Lengkap (RAL) dengan 4 perlakuan dan masing masing perlakuan terdiri dari 3 ulangan sehinga terdapat 12 unit percobaan dengan starter yang berbeda, dengan perlakuan sebagai berikut :

$\mathrm{P} 0=$ kulit pisang goroho tanpa fermentasi.

$\mathrm{P} 1=$ kulit pisang goroho difermentasi Rhizopus olygosphorus $0.3 \%$.

P2 = kulit pisang goroho difermentasi Trichoderma viride $0.3 \%$.

P3 = kulit pisang goroho difermentasi Rhizopus olygosphorus $0.15 \%+$ Trichoderma viride 0.15 .

\section{Analisis Data}

Data yang diperoleh dianalisis secara statistik dengan menggunakan sidik ragam sesuai rancangan acak lengkap (RAL), seperti rumus yang disarankan oleh Pasue, I. I. (2019). 


$$
\mathrm{Y}_{\mathrm{ijk}}=\mu+\alpha \mathrm{i}+€_{\mathrm{ijk}}
$$

Keteragan :

$\mathrm{Y}_{\mathrm{ij}}=$ nilai pengamatan pada fermentasi pisang goroho ke-i ulangan ke-j

$\mu=$ nilai tengah (rata-rata) fermentasi pisang Goroho ke-i ulangan ke-j

$a \mathrm{i}=$ pengaruh fermentasi pisang Goroho ke-i $\varepsilon_{\mathrm{ij}}=$ galat perlakuan ransum ke-i ulangan ke-j Uji lanjut perlakuan berpengaruh nyata maka diuji lebih lanjut dengan uji beda

Tabel 1. Rata-rata analisis lignin dan tannin kulit pisang goroho difermentasi menggunakan Rhizopus olygosporus dan Trichoderma viride dengan stater yang berbeda

\begin{tabular}{lcccc}
\hline \multirow{2}{*}{ Variabel } & \multicolumn{4}{c}{ Perlakuan } \\
\cline { 2 - 5 } & P0 & P1 & P2 & P3 \\
\hline Lignin & $17,55^{\mathrm{b}}$ & $16,73^{\mathrm{ab}}$ & $19,55^{\mathrm{c}}$ & $16,23^{\mathrm{a}}$ \\
Tannin & $0,54^{\mathrm{b}}$ & $0,2^{\mathrm{a}}$ & $0,63^{\mathrm{bc}}$ & $0,68^{\mathrm{c}}$ \\
\hline
\end{tabular}

Keteragan : Superskrip yang berbeda pada baris yang sama menujukan berpengaruh sangat nyata $(\mathrm{P}<0.01)$, P0=Kontrol, P1= kulit pisang difermentasi dengan Rhizopus olygosporus 0,3\%, P2= kulit pisang goroho terfermetasi dengan Trichoderma viride $0.3 \%, \mathrm{P} 3=$ kulit pisang goroho terfermentasi dengan Rhizopus olygosporus $0.15 \%+$ Trhichoderma viride 0.15 .

Kandungan Lignin pada Kulit Pisang Goroho Terfermetasi

Hasil pengamatan dan perhitugan persentase perubahan kandugan liqnin dari masing-masing perlakuan yang diberikan selama penelitian dapat dilihat dari tabel 1. Data hasil penelitian menujukan persentase perubahan kandugan lignin kulit pisang goroho yang terfermentasi bervariasi berkisar antara $16,23 \%-19,55 \%$. Persentase perubahan kandungan lignin tertiggi pada perlakuan lignin P2 kulit pisang terfermentasi dengan Trichoderma viride $0,3 \%$ yaitu $19,55 \%$ dan persentase perubahan kandungan kandugan liqnin terendah diperoeh pada perlakuan P3 kulit pisang fermentasi Trichoderma viride 1,5 \%+ Rhizopus olygosporus 1,5\% yaitu 16,23\%.

Hasil analisis sidik ragam menujukan bahwa fermentasi kulit pisang goroho dengan Rhizopus olygosporus dan Trichoderma viride memberi pegaruh sangat nyata $(\mathrm{P}<0,01)$ terhadap kandugan lignin. Uji lanjut menujukan bahwa kandungan lignin P3 kulit pisang goroho fermentasi Trichoderma viride 1,5\% dan Rhizopus olygosporus 1,5 \% yaitu 16,23 nyata lebih rendah $(\mathrm{P}<0,01)$ dengan kandungan lignin P2 kulit pisang terfermentasi dengan Trichoderma viride 0,3\% yaitu 19,55, P0 tanpa fermentasi yaitu17.55 dan P1 kulit pisang goroho terfermetasi dengan Rhizopus olygosporus $0,3 \%$ yaitu $16,73 \%$.

Dalam penelitian ini perlakuan P3 memiliki daya cerna karena semakin rendah kandungan Lignin semakin tinggi tingkat kecernaan zat makanan dan semakin positif peluang untuk dimanfaatkan sebagai sumber bahan pakan. Tetapi dalam penelitian ini rataan nilai lignin cukup tinggi dan melebihi dari batas maksimal lignin yang dapat ditolerasi oleh ternak yaitu sebesar 7\% (Goering dan Vansoest,1970).

Kandungan lignin pada kulit pisang menunjukkan bahwa penambahan jamur Tricoderma viride dan Rhizopus olygosporus mampu mendegradasi kandungan lignin. Penelitian ini sejalan dengan pendapat Murni, dkk (2008) menyatakan bahwa mikroorganisme dapat mendegradasi senyawa lignin sehingga meningkatkan daya cerna pakan, mikroorganisme Rhizopus olygosporus yang ideal dalam biokonversi lignoselulosa menjadi pakan ternak adalah mikroorganisme Rhizopus oligosphorus yang mempunyai kemampuan besar 
dalam mendekomposisi lignin tetapi rendah daya degradasinya terhadap selulosa dan hemiselulosa. Bahri (2008) menyatakan bahwa serat kasar yang tinggi tidak hanya sulit dicerna tetapi juga menyebabkan beberapa zat makanan terikut keluar dalam ekskreta. Wahju (2004) menambahkan bahwa faktor utama yang mempengaruhi konsumsi pakan adalah kandungan energi metabolisme dalam pakan serta serat kasar yang tinggi tidak dapat dimanfaatkan oleh unggas karena unggas tidak mempunyai enzim yang dapat mencerna serat kasar. Kualitas pakan didalam memformulasi pakan perlu diperhatikan agar pakan yang telah diformulasikan itu mampu diperoleh ternak yang bersangkutan dan jumlah zatzat makanan yang dibutuhkan dapat dipenuhi karena masing-masing ternak mempunyai keterbatasan dalam mengkonsumsi pakan (Siregar, 1991).

\section{Kandungan Tanin pada Kulit Pisang Goroho Terfermetasi}

Hasil pengamatan dan perhitugan persentase perubahan kandugan tannin dari masing-masing perlakuan yang diberikan selama penelitian dapat dilihat dari Tabel 1. Data hasil penelitian menujukan persentase perubahan kandugan tannin kulit pisang goroho yang terfermentasi bervariasi berkisar antara $0,20 \%-0,68 \%$. Persentase perubahan kandungan tannin tertiggi pada perlakuan P3 fermentasi Rhizopus olygosporus 0,15\% + Trichoderma viride $0,15 \%$ yaitu $0,68 \%$ dan persentase perubahan kandungan lignin terendah diperoeh pada perlakuan P1 fermentasi Rhizopus olygosporus $0,3 \%$ yaitu $0,20 \%$. Hasil analisis sidik ragam menujukan bahwa fermentasi kulit pisang goroho dengan Rhizopus olygosporus dan Trichoderma viride memberi pegaruh sangat nyata $(\mathrm{P}>0,01)$ terhadap perubahan kandugan tanin.

Uji lanjut menujukan bahwa kandungan tannin P1 kulit pisang goroho terfermetasi dengan Rhizopus olygosporus $0,3 \%$ yaitu $0,20 \%$ nyata lebih rendah $(\mathrm{P}<0,01)$ dengan kandungan tannin $\mathrm{P} 3$ kulit pisang goroho terfermentasi dengan Rhizopus olygosporus 0,15\% + Trichoderma viride $0,15 \%$ yaitu $0,68 \%$, P2 kulit pisang terfermentasi dengan Trichoderma viride $0.3 \%$ yaitu $0,63 \%$ dan P0 kulit pisang (control) tanpa fermentasi yaitu $0.54 \%$.

Dalam penelitian ini limbah kulit pisang goroho memiliki kandungan tannin dengan rataan $0,20 \%$ pada perlakuan P1, sementara batas penggunaan tanin dalam ransum adalah 0,33\% (Widodo, 2002). Sehingga limbah kulit pisang goroho yang difermentasi menggunakan jamur Rhizopus olygosporus memiliki daya cerna sebagai pakan ternak ayam ras petelur. Menurunnnya tannin ini karena adannya proses pemecahan protein dan karbohidrat oleh enzim-enzim hasil metabolisme mikroorganisme mejadi senyawa yang jauh lebih sederhana (Komari,1999). Menurut Widodo (2005) meyatakan bawha pengaruh tannin dapat dihilangkan dengan perendaman dalam air, perendaman dalam larutan alkali, cara mekanis, dan suplementasi donor metal, dan pemanasan. Bila dibandingkan dengan penelitian Konten, B., (2010) biji asam tanpa fermentasi mengandug tannin sebesar $5,72 \%$ setelah dilakukan fermentasi dengan Rhizopus olygosporus ini menurunkan kadar tannin menjadi 0,43 hingga 0,34. Jadi jelas terlihat bahwa fermetasi dapat menurukan zat anti nutrisi sesuai dengan pernyataan Suliantari dan Rahayu (1990).

Tingginya kandungan tannin dalam kulit pisang dapat meurunkan daya cerna karena tannin dapat mengikat protein,selulosa dan hemiselulosa sehingga aktifitas enzim protease dan ezim selulase menjadi terhambat. Hal ini sejalan dengan pendapat Hartutik (2000) bahwa tannin merupakan senyawa polifenol kompleks yang mempunyai sifat dapat berikatan degan protein atau polimer lainnya seperti selulosa, hemiselulosa dan pectin membentuk suatu ikatan kompleks yang stabil, sehingga dapat meghambat kerja enzim (tripsin dan khimotripsin) dan enzim selulase. 


\section{KESIMPULAN}

Berdasarkan hasil penelitian yang telah dilakukan dapat disimpulkan bahwa kulit pisang goroho dapat dimanfaatkan sebagai pakan ternak ayam ras petelur adalah yang difermentasi dengan Rhizopus olygosporus 1,5\% + Trichoderma viride 1,5\% yang memiliki kandungan lignin sebesar $16,23 \%$ dan yang difermentasi dengan Rhizopus olygosporus memiliki kandungan tannin sebesar $0,20 \%$.

\section{DAFTAR PUSTAKA}

Bahri, S dan Rusdi. 2008. Evaluasi Energi Metabolis Pakan Lokal Pada Ayam Petelur. http:// jurnal.untad.ac.id /jurnal. index.php/ AGROLAND/ article/view/163/135.

Goering, H. K. And P. J. Van Soest. 1970. Forage Fiber Analisys. Argicultural. Handbook 379 A. R. S., Inc., Englewood Cliffs, New York.

Gomez dan Gomez. 2010. Prosedur Statistika Untuk Penelitian Pertanian. Universitas Indonesia. Jakarta.

Hartutik, 2000. Uji kandungan tanin pada bungkil biji kapuk (Ceiba pentandra, Gaertn.) dengan polyethylene glycol melalui pengukuran produksi gas secara In vitro. Buletin Peternakan. Hal 83-87

Komari. 1999. Proses Fermentasi Biji Lamtoro-Gung dengan Rhizopus oryzae. Jurnal Mikrobiologi Indonesia, Februari 1999, Vol. 4.No. 1. Hal. 19-21

Konten Bernadete. 2010. Perubahan Anti Nutrisi Pada Silase Buah Semu
Jambu Mete Sebagai Pakan Dengan Menggunakan Berbagai Aras Tepung Gaplek Dan Lama Pemeraman. Buletin Peternakan Vol. 34(2): 82-85, Juni 2010

Murni, R, Suparjo, Akmal, dan B.L.Ginting. 2008. Buku Ajar Teknologi Pemanfaatan Limbah untuk Pakan. Laboratorium Makanan Ternak. Fakultas Peternakan universitas Jambi.

Pasue, I. I. 2019. Analisis Lignin, Selulosa dan Hemi Selulosa Jerami Jagung Hasil Di Fermentasi Trichoderma Viride Dengan Masa Inkubasi Yang Berbeda. Jambura Journal of Animal Science, 1(2), 62-67.

Siregar, Z. 1991. Komposisi Zat-Zat Nutrisi Dalam Pakan Unggas. USU Press. Medan

Suliantari dan W. P. Rahayu. 1990. Teknologi Biodegradasi Bijibijian dan Umbi-umbian. Depdikbud dan Pusat Antar Universitas Pangan dan Gizi. IPB. Bogor.

Wahju, J. 2004. Ilmu Nutrisi Unggas. UGM Press. Yogyakarta

Widodo, W. 2005. Tanaman Beracun dalam Kehidupan Ternak, Penerbit Universitas

Widodo, wahyu. 2002. Nutrisi Dan Pakan Kontekstual. http:/ /wahyuwidodo.s taff.umm.ac.id/files /2010 /01/ Nutrisi_Dan_Pakan_Unggas_Kont Ekstual.Pdf (Diakses 7 April 2016). 